\title{
A New Marine Nematode Species, Metalinhomoeus ramsarensis (Linhomoeidae Filipjev, 1922) from Kuching Wetland National Park, Sarawak, Malaysia
}

\author{
CHENG-ANN CHEN*1,2 \& SHABDIN MOHD LONG ${ }^{1}$ \\ ${ }^{I}$ Department of Aquatic Science, Faculty of Resource Science and Technology, Universiti Malaysia \\ Sarawak, 94300 Kota Samarahan, Sarawak, Malaysia; ${ }^{2}$ Borneo Marine Research Institute, Universiti \\ Malaysia Sabah, Jalan UMS, 88400 Kota Kinabalu, Sabah, Malaysia
}

\begin{abstract}
A new marine nematode species from the genus Metalinhomoeus (de Man, 1907) was found in Kuching Wetland National Park (KWNP). The total body size of Metalinhomoeus ramsarensis sp. nov. was extremely long. The head was recorded to be round with four cephalic setae followed by four sub cephalic setae. The inner and outer labial papillae were not clearly observed. An oesophageal bulb was present at the end of the oesophagus. Spicules were known to have central cuticularized strip. Tail of Metalinhomoeus ramsarensis sp. nov. was short and blunt.
\end{abstract}

Keywords: Metalinhomoeus, marine nematode, RAMSAR, Sarawak, Kuching Wetland National Park

\section{INTRODUCTION}

Malaysia is renowned with the richness of biodiversity yet the documentations of freeliving marine nematodes are still inadequate. Several efforts were carried out to document the diversity of free-living marine nematode in Malaysia: ecology (Chen et al., 2012a \& b; Sasekumar, 1994; Shabdin \& Othman, 1999 \& 2005) and taxonomy (Chen, 2015; Norliana et al., 2013; Shabdin et al., 2013). This is followed by the new genus Pseudoplatycoma malaysianis, which was lately described by Chen (2015) in Sabah, a new marine nematode species from the genus Metalinhomoeus was found in Kuching Wetland National Park (KWNP).

Genus Metalinhomoeus was erected by de Man in 1907 in order to separate Metalinhomoeus typicus from Paralinhomoeus. Both genera were generally known to have several similar characteristics such as small buccal cavity which were unarmed, presence of sub cephalic setae, amphid circular and gubernaculum with apophysis. The two genera (Metalinhomoeus and Paralinhomoeus) basically can be distinguished by the different numbers of cephalic setae and presence of posterior oesophageal bulb (number of cephalic setae: 4 vs 10; bulb: present $v s$ absent) (de Man, 1907; Platt \& Warwick, 1983).

\section{MATERIALS \& METHODS}

Only one male specimen was collected from Loba Kilong (N 0141.375' E110 ${ }^{\circ} 12.572^{\prime}$ ), Kuching, Sarawak, Malaysia by the first author on April 2011. The present species was found in subtidal muddy samples during high tide.

A grab sampler was used to collect the subtidal samples. Samples were preserved in 5\% formalin in the field and were brought back to the laboratory for further analysis and identification. Samples were sieved using a 500 $\mu \mathrm{m}$ mesh size sieve and rinsed with tap water to remove the formalin. Residues that retained on the sieve were transferred to a Petri dish and sorted under stereomicroscope. Then, they were mounted on slide using standard method as in Chen and Shabdin (2015).

The nematode morphology and characteristic were observed and drawn using compound microscope equipped with Camera Lucida (Model Olympus BX 51). The identifications were based on several keys of identification (Warwick et al., 1998). The following abbreviations were used in the present study:

*Corresponding author: chengann@ums.edu.my 
a, b, c (de Man's ratios); c' (tail length/a.b.d); a.b.d. (anal/cloacal body diameter); c.d. (corresponding diameter); Sa (length of spicule along the arc); and Sc (length of spicule along the chord).

Type sample (MAS.NEM.01) is deposited in the Museum of Aquatic Sciences of Universiti Malaysia Sarawak.

\section{TAXONOMY}

Order Monhysterida

Family Linhomoeidae Filipjev, 1922

Genus Metalinhomoeus de Man, 1907

Metalinhomoeus ramsarensis sp. nov.

(Table 1; Figure 1-2)

\section{MALE (Holotype)}

MAS.NEM.01 Habitat: Muddy. Specimen illustrated in ventral view. Total body length long $7475 \mu \mathrm{m}(\mathrm{a}=108.66 ; \mathrm{b}=28.94 ; \mathrm{c}=$ 110.99). Head rounded. Inner and outer labial papillae not clearly observed. Four cephalic setae $(4.74 \mu \mathrm{m})$ followed by four sub cephalic setae. Buccal cavity minute. Amphid round (11.08 $\mu \mathrm{m}$ width) and located posterior to the sub cephalic setae. Oesophagus is cylindrical (length $258.28 \mu \mathrm{m}$ ). Oesophagus c.d. 25.19 $\mu \mathrm{m}$. Bulb present at the end of the oesophagus (39.78 $\mu \mathrm{m}$ width). Nerve ring not observed. Spicules paired; curved; proximal end spicule bluntly rounded; distal end slightly pointed. Length of the spicule in arc, $72.51 \mu \mathrm{m}$ with central cuticularized strip. Gubernaculum length $22.26 \mu \mathrm{m}$ with cylindrical apophysis. No precloacal supplements were observed. Caudal setae absent. Tail short and blunt $(67.35 \mu \mathrm{m}$ in length; c' = 1.47).

\section{ETYMOLOGY}

The species name refers to the location where the specimen was found which was gazette as a RAMSAR site.

\section{DISCUSSION}

A total of 33 species had been described under genus Metalinhomoeus. Out of the 33 species, only Metalinhomoeus karachiensis Timm, 1962, Metalinhomoeus insularis Timm, 1967 and Metalinhomoeus sunderbanae Timm, 1967 were recorded from the tropical waters. The present species has central cuticularized strip together with short and blunted tail. Although several recorded species (Metalinhomoeus filiformis de Man, 1907; Metalinhomoeus typicus de Man, 1907; Metalinhomoeus gracilis Kreis, 1929; Metalinhomoeus longiseta Kreis,

Table 1. Measurements of Metalinhomoeus ramsarensis sp. nov.

\begin{tabular}{lc}
\hline Characteristics & Measurements $(\boldsymbol{\mu m})$ \\
\hline Total body length & 7475 \\
Head diameter & 12.42 \\
Length of cephalic setae & 4.74 \\
Amphid diameter & 11.08 \\
Amphid diameter / c.d \% & 48.88 \\
Oesophagus length & 258.28 \\
Oesophagus c.d & 25.19 \\
Oesophagus end diameter & 39.78 \\
Maximum body diameter & 68.79 \\
Sc & 63.75 \\
Sa & 72.51 \\
Length of gubernaculum & 22.26 \\
Tail length & 67.35 \\
a.b.d. & 45.8 \\
a & 108.66 \\
b & 28.94 \\
c & 110.98 \\
c' & 1.47 \\
\hline
\end{tabular}




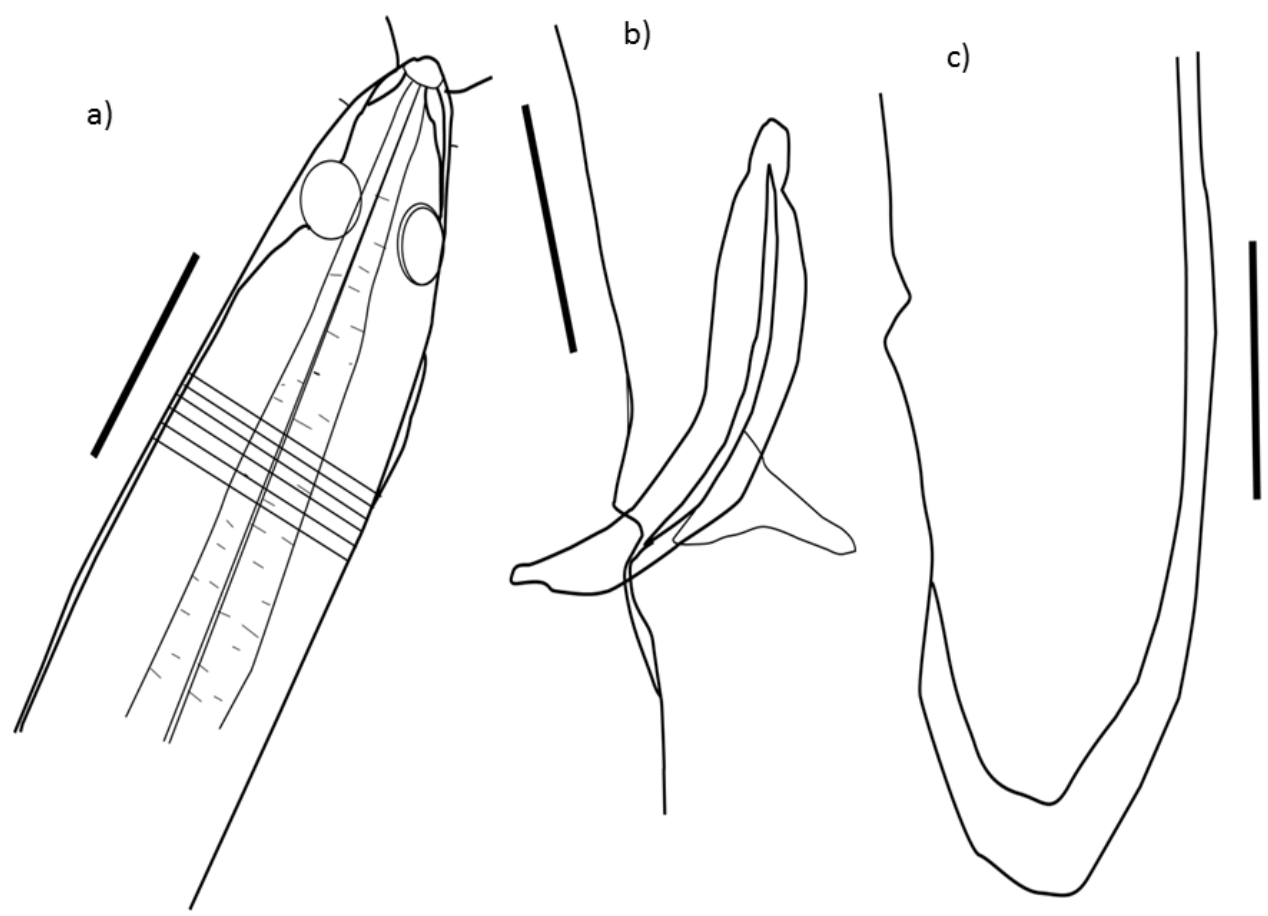

Figure 1. a) head, b) spicule and c) tail region of Metalinhomoeus ramsarensis sp. nov. Scale bar: $20 \mu \mathrm{m}$.

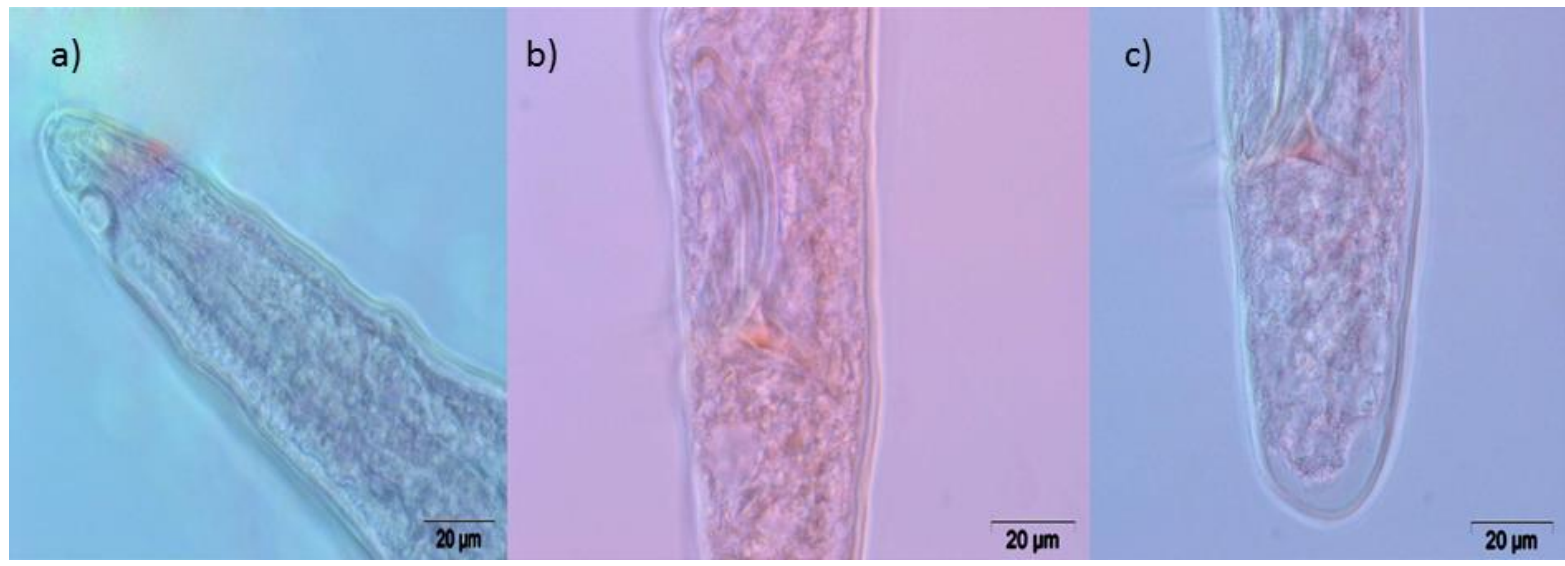

Figure 2. a) head, b) spicule and c) tail of Metalinhomoeus ramsarensis sp. nov.

1929; Metalinhomoeus breviseta Schuurmans Stekhoven, 1950; Metalinhomoeus musaecauda Lorenzen, 1966; Metalinhomoeus parvasetosus Vitiello, 1969; Metalinhomoeus torosus Jensen \& Gerlach, 1976; Metalinhomoeus numidicus Aissa \& Vitiello, 1977) were known to have spicules with central cuticularized strip, yet the tail of these species were either conicocylindrical or filiform. None was recorded with short and blunted tail. The size of $M$. ramsarensis sp. nov. is the longest long (7475 $\mu \mathrm{m})$ among all the species ever described. Previously, Metalinhomoeus trichosoma Allgén, 1959 was the longest $(4606 \mu \mathrm{m})$ but comparatively still $39 \%$ smaller in size. Besides that, the spicules of $M$. trichosoma were recorded with no central cuticularized strip and not to mention the absence of short and blunted tail. With all of the evidences provided above, we are here to validate the present species $M$. ramsarensis sp. nov. as a new member of the genus Metalinhomoeus. 


\section{ACKNOWLEDGEMENTS}

This study was supported by the Ministry of Education (MOE), Malaysia through FRGS/STWN 04(01)/1062/2013(08). We would like to thank Universiti Malaysia Sarawak for providing the facilities and the administrative and logistic support during field work. Special thanks to Mr. Richard Toh, Mr. Azlan and Mr. Zaidi for their help during the sampling periods.

\section{REFERENCES}

Aissa, P. \& Vitiello, P. (1977). Nouvelles espèces de Nématodes libres de la lagune de Tunis Bulletin Societe Sciences Naturelles Tunisie, 12: 45-52.

Allgén, C.A. (1959). Free living marine nematodes (Further zoological results of the Swedish Antarctic expedition, 1901-1903). P.A. Norstedt \& Söner: Stockholm. Pp. 293.

Chen, C.A. (2015). A new marine nematode genus Pseudoplatycoma with a new species from the Sulu Sea and revision of the subfamily Platycominae (Enoplida: Leptosomatidae). Zootaxa, 3905(2): 233244.

Chen, C.A. \& Shabdin, M.L. (2015). A new species of Setosabatieria Platt, 1985 (Nematoda: Comesomatidae) from Chek Jawa, Singapore, with a key to valid species of the genus. Marine Biology Research, 11(2): 203-208.

Chen, C.A., Shabdin, M.L., \& Norliana, M.R. (2012a). Spatial distribution of tropical estuarine nematode communities in Sarawak, Malaysia (Borneo). The Raffles Bulletin of Zoology, 60(1): 173-181.

Chen, C.A., Shabdin, M.L., \& Norliana, M.R. (2012b). An ecological study of free-living marine nematodes in Teluk Awar, Sarawak, Malaysia. Borneo Journal of Resource Science and Technology, 2: 1-10.

De Man, J.G. (1907). Sur quelques espèces nouvelles ou peu connues de Nématodes libres vivant sur les côtes de la Zélande. Tijdschrift der Nederlandsche Dierkundige Vereeniging, 10: 227-244.
Jensen, P. \& Gerlach, S.A. (1976). Three new nematodes from Bermuda. Veroeffentlichungen des Instituts fuer Meeresforschung in Bremerhaven, 16: 3144.

Kreis, H. (1929). Freilebende marine Nemaden von der Nordwest-Küste Frankreichs (Trébeurden Côtes du Nord). Capita Zoologica, 2(7): 1-98.

Lorenzen, S. (1966). Diagnosen einiger freilebender Nematoden von der Schleswig -holsteinischen. Veroeffentlichungen des Instituts fuer Meeresforschung in Bremerhaven, 10: 31-48.

Norliana, M.R., Shabdin, M.L. \& Chen, C.A. (2013). A new record from east Malaysia: Sphaerolaimus macrocirculus (Nematoda). Borneo Journal of Resource Science and Technology, 2(2): 12-18.

Platt, H.M. \& Warwick, R.M. (1983). Freeliving marine nematodes. Part I. British Enoplids. In D.M. Kermack \& R.S.K. Barnes (Eds.), Synopses of the British Fauna No. 28. Cambridge: Cambridge University Press. Pp 307.

Schuurmans Stekhoven Jr., J.H. (1950). The free-living marine nemas of the Mediterranean: I. The Bay of Villefranche. Mémoires de l'Institut Royal des Sciences Naturelles de Belgique, 37: 1-220.

Sasekumar, A. (1994). Meiofauna of a mangrove shore on the west coast of Peninsular Malaysia. Raffles Bulletin of Zoology, 42(4): 901-915.

Shabdin, M.L. \& Othman, B.H.R. (1999). Vertical distribution of nematodes (Nematoda) and harpaticoid copepods (Copepoda: Harpacticoida) in muddy and sandy bottom of intertidal zona at Lok Kawi, Sabah, Malaysia. Raffles Bulletin of Zoology, 47(2): 349-363.

Shabdin, M.L. \& Othman, B.H.R. (2005). Seasonal variations of marine nematode assemblages in Sabah, Malaysia. The Philippine Scientist, 42: 40-66.

Shabdin, M.L, Norliana, M.R., \& Chen, C.A. (2013). Free-living marine nematodes in Sarawak coastal waters. Universiti Malaysia Terengganu. 
Timm, R.W. (1962). Marine nematodes of the family Linhomoeidae from the Arabian Sea at Karachi. Canadian Journal of Zoology, 40: 165-178.

Timm, R.W. (1967). New marine nematodes of the family Linhomoeidae from East Pakistan. Proceedings of Pakistan Academy of Sciences, 4(1): 15-22.
Vitiello, P. (1969). Linhomoeidae (Nematoda) des vases profondes du Golfe du Lion. Téthys, 1(2): 493-527.

Warwick, R.M., Platt, H.M., \& Sommerfield, P.J. (1998). Free-living nematodes (Part III) Monhysterids. In R.S.K. Barnes \& J.H. Crothers (Eds.), Synopsis of British Fauna, No. 53. Shewsbury: Field Studies Council. Pp 296. 